IOS Press

\title{
Cranberry proanthocyanidins modulate reactive oxygen species in Barrett's and esophageal adenocarcinoma cell lines
}

\author{
Katherine M. Weh ${ }^{\mathrm{a}}$, Harini S. Aiyer ${ }^{\mathrm{a}}$, Amy B. Howell ${ }^{\mathrm{b}}$ and Laura A. Kresty ${ }^{\mathrm{a}, *}$ \\ ${ }^{a}$ Department of Medicine, Division of Hematology and Oncology, Medical College of Wisconsin, Milwaukee, \\ WI, USA \\ ${ }^{\mathrm{b}}$ Department of Plant Pathology and Biology, Marucci Center for Blueberry and Cranberry Research, Rutgers \\ University, Chatsworth, NJ, USA
}

Received 23 December 2015; accepted 31 January 2016

\begin{abstract}
.
BACKGROUND: We recently reported that a cranberry proanthocyanidin rich extract (C-PAC) induces autophagic cell death in apoptotic resistant esophageal adenocarcinoma (EAC) cells and necrosis in autophagy resistant cells. EAC is characterized by high morbidity and mortality rates supporting development of improved preventive interventions.

OBJECTIVE: The current investigation sought to investigate the role of reactive oxygen species (ROS) in the context of C-PAC induced cell death.

METHODS: A panel of human esophageal cell lines of EAC or BE (Barrett's esophagus) origin were treated with C-PAC and assessed for ROS modulation using CellROX ${ }^{\circledR}$ Green reagent and the Amplex Red assay to specifically measure hydrogen peroxide levels.

RESULTS: C-PAC significantly increased ROS levels in EAC cells, but significantly reduced ROS levels in CP-C BE cells. Increased hydrogen peroxide levels were also detected in C-PAC treated EAC cells and supernatant; however, hydrogen peroxide levels were significantly increased in medium alone, without cells, suggesting that C-PAC interferes or directly acts on the substrate. Hydrogen peroxide levels did not change in C-PAC treated CP-C BE cells.

CONCLUSION: These experiments provide additional mechanistic insight regarding C-PAC induced cancer cell death through modulation of ROS. Additional research is warranted to identify specific ROS species associated with C-PAC exposure.
\end{abstract}

Keywords: Cranberry proanthocyanidins, esophageal adenocarcinoma, Barrett's esophagus, ROS, JHAD1, OE33, OE19, CP-C, hydrogen peroxide

\section{Introduction}

Numerous health benefits are attributed to cranberry consumption, a small red berry for which over 150 different phytonutrients are described [1]. Cranberry, whether as a juice or extract, imparts urinary tract and cardiovascular health benefits clinically [2,3]. More recently, preclinical models support cancer inhibitory capacity against numerous cancers including esophageal adenocarcinoma (EAC), ovarian, prostate, breast and lung [4-14]

* Corresponding author: Laura A. Kresty, Medical College of Wisconsin, Division of Hematology and Oncology, Department of Medicine, TBRC \#3910, 8701 Watertown Plank Road, Milwaukee, WI 53226, USA. Tel.: +1 414955 2637; E-mail: LKresty@mcw.edu.

1878-5093/16/\$35.00 @ 2016 - IOS Press and the authors. All rights reserved

This article is published online with Open Access and distributed under the terms of the Creative Commons Attribution Non-Commercial License. 
with the strongest in vivo effect seen in bladder and colon cancer $[15,16]$. The best known health-associated use of cranberries is in the prevention and treatment of urinary tract infections caused by uropathogenic Escherichia coli $[17,18]$. Flavonoids are one major class of cranberry bioactive components and include anthocyanins, flavonols and proanthocyanidins (PAC). Cranberry's ability to inhibit urinary tract infections is largely attributed to the PAC fraction $[1,19,20]$. Antioxidant effects of these polyphenolic compounds are widely reported and include the ability to decrease lipid oxidation and alter overall markers of oxidative stress [21]. The cranberry proanthocyanidins, also termed C-PAC, are polymers of catechin and epicatechin units with 2-10 degrees of polymerization and at least one or more A-type linkages [1, 2, 21]. The C-PACs are found at fairly high concentration in the cranberry [133-367 mg/100 $\mathrm{g}$ fruit; 2].

With respect to cancer, C-PAC is a potent inhibitor of EAC in vitro and in vivo with a $67.6 \%$ reduction in OE19 tumors using a mouse xenograft model $[8,14]$. Esophageal cancer is the 7 th leading cause of cancer mortality among US males with a 5 year survival rate consistently below $20 \%$ [22, 23]. Improved methods for screening, prevention and treatment are needed. Barrett's esophagus (BE), the only identified precursor lesion of EAC, is the result of gastroesophageal reflux disease (GERD) [24-26]. The mechanism of progression from BE to EAC is currently under investigation but likely is multifactorial and characterized by increased genetic abnormalities, including somatic chromosomal alterations preceding cancer [27, 28]. Recently our lab has shown that C-PAC induces autophagic cell death in apoptosis resistant EAC cell lines [8, 14]. Furthermore, autophagy induction was not dependent on Beclin-1, a key regulator of autophagy, in EAC lines [14]. Parallel to in vivo xenograft results, C-PAC treatment of EAC cells resulted in downregulation of the PI3K/AKT/mTOR pathway, the central axis for induction of the autophagic cell death pathway.

The association of reactive oxygen species (ROS) and cell death induction is established for cellular necrosis and more recently in the context of autophagy [29]. The overproduction and release of ROS is characteristic of necrotic cell death, while ROS have been shown to regulate autophagy [30,31]. ROS including superoxide, hydroxyl radical and hydrogen peroxide are generated under conditions of oxidative stress, with increased levels of oxidative damage resulting in activation of cell death pathways [32]. Basal ROS levels in cells act as signaling molecules for growth adaptation and survival. Cancer cells are documented to have higher levels of ROS due to altered metabolic machinery which predisposes cancer cells to increased levels of protein, DNA and lipid damage [29]. Generation of ROS are implicated in the progression of normal cells to cancer cells with cancer cells frequently developing resistance to oxidative stress [33, 34]. A further increase above the heightened basal level of ROS in cancer cells can result in cell death. This in turn has led to the development of several ROSinducing drugs including cisplatin (used to treat EAC), cyclophosphamide and fenretidine [35, 36]. Increased ROS levels have been reported in patients with esophagitis and Barrett's esophagus compared to healthy controls and the increased oxidative stress is hypothesized to contribute to carcinogenesis of the esophageal mucosa $[37,38]$. Therefore an understanding of the oxidative environment of BE and EAC is important for characterizing the cell death mechanism induced by treatment with C-PAC. ROS is known to be involve in progression to BE and EAC. Two recent reports in ovarian cancer and neuroblastoma reported pro-oxidant effects linked to cell death induction $[6,39]$. In this study, we sought to determine the effects of C-PAC on ROS modulation of EAC and BE cells. C-PAC induced generation of ROS in EAC lines with significant increases in hydrogen peroxide observed for JHAD1 and OE19 cells. Conversely, levels of ROS were reduced in C-PAC treated CP-C BE cells.

\section{Materials and methods}

\subsection{Cranberry extract isolation and purification}

Cranberry fruit (Vaccinium macrocarpon Ait.) was collected at the Marucci Center for Blueberry and Cranberry Research, Chatsworth, NJ. Purified C-PAC extract was isolated from cranberries of the 'Early Black' cultivar utilizing solid-phase chromatography as previously described extensively [8, 19, 40-42]. Purified freeze-dried 
C-PAC was stored at $-80^{\circ} \mathrm{C}$ until used in experiments where it was diluted in treatment medium with a final concentration of $\leq 0.001 \%$ ethanol.

\subsection{Cell culture}

Authenticated human BE and EAC cell lines were utilized in this series of experiments. CP-C cells were purchased from ATCC (CRL-4029) and maintained in complete BE growth medium with 5\% fetal bovine serum (FBS) as recommended by ATCC. JHAD1 cells were isolated from a distal EAC, stage III, N0 in 1997 (kind gift from Dr. James Eshleman, Johns Hopkins University, Baltimore, MD), OE33 cells were isolated in 1993 from a distal EAC, stage II, N0 (ECACC, Wiltshire, UK) and OE19 cells were isolated in 1993 from an adenocarcinoma at the gastro-esophageal junction, stage III, N1 (ECACC, Wiltshire, UK). EAC cells were grown in RPMI 1640 complete medium containing L-glutamine $(2.0 \mathrm{mM})$, penicillin $\left(10^{4}\right.$ units $\left./ \mathrm{mL}\right)$, streptomycin $\left(10^{4} \mu \mathrm{g} / \mathrm{mL}\right)$, sodium pyruvate $(1 \mathrm{mM})$ and $10 \%$ fetal bovine serum. All cell culture reagents were from ThermoFisher Scientific (Waltham, MA). Cells were maintained as monolayers at $37{ }^{\circ} \mathrm{C}$ with $95 \%$ air and $5 \% \mathrm{CO}_{2}$. In all tissue culture assays, the vehicle was $\leq 0.001 \%$ ethanol diluted in the appropriate medium.

\subsection{CellROX $^{\circledR}$ green detection of $R O S$}

C-PAC modulation of oxidative stress was measured using CellROX ${ }^{\circledR}$ Green reagent, a non-specific indicator of ROS, based on the manufacturer's recommendations (ThermoFisher Scientific, Waltham, MA). When in a reduced state, CellROX ${ }^{\circledR}$ Green is a weakly fluorescent cell-permeable dye that exhibits bright green photo stable fluorescence upon oxidation by ROS and subsequent binding to DNA. JHAD1 (10E3 cells/well), OE33 (10E3 cells/well) and OE19 (15E3 cells/well) EAC cells were plated in 96-well black walled, clear bottom plates (Greiner Bio One, Monroe, NC). CP-C BE cells were plated at 10E3 cells/well in the same plates. Cells adhered for $26-30 \mathrm{~h}$ and were treated for 3 or $6 \mathrm{~h}$ with vehicle, the ROS inducer tert-Butyl Hydroperoxide (TBHP; $100 \mu \mathrm{M}$ final concentration; positive control; ThermoFisher Scientific, Waltham, MA) or C-PAC [25 $\mu \mathrm{g} / \mathrm{ml}$ to $100 \mu \mathrm{g} / \mathrm{ml}$ ] alone or in combination with the antioxidant $N$-acetyl- $L$-cysteine (NAC; $5 \mathrm{mM}$ final concentration; Sigma-Aldrich, St. Louis, MO). C-PAC concentrations were selected based on previous studies which determined the LD50 to be in the 50 to $100 \mu \mathrm{g} / \mathrm{mL}$ range in various cancer cell lines [7, 43, 44]. The concentrations of $\mathrm{C}$-PAC used in these experiments are readily achievable in humans and are already under evaluation for oral and urinary tract health benefits. All treatments were diluted in phenol-red free RPMI complete media with $5 \%$ FBS and complete BE growth medium with 5\% FBS for EAC and BE cells respectively. CellROX ${ }^{\circledR}$ Green reagent was added to the cells and incubated for $30 \mathrm{~min}$ at $37^{\circ} \mathrm{C}$, subsequently washed once with PBS prior to fluorescent detection using the SpectraMax ${ }^{\circledR}$ i3 Multi-Mode Detection Platform. Cellular imaging was done using the SpectraMax ${ }^{\circledR}$ MiniMax ${ }^{\text {TM }}$ Imaging Cytometer with excitation/emission wavelengths of 460/535 nm. The data were analyzed using the SoftMax ${ }^{\circledR}$ Pro 6.2 Software. A minimum of 4 wells were analyzed for each treatment and expressed as a mean percentage of vehicle treated cells $\pm \mathrm{SEM}$.

\subsection{Amplex red hydrogen peroxide assay}

Hydrogen peroxide levels were measured following C-PAC treatment of EAC and BE cells using the Amplex Red Hydrogen Peroxide/Peroxidase kit according to the manufacturer's recommendations (ThermoFisher Scientific, Waltham, MA). JHAD1 and OE19 EAC cells were plated at 10E3 and 15E3 cells/well, respectively in 96-well black walled, clear bottom plates (Greiner Bio One, Monroe, NC). CP-C BE cells were plated at $8 \mathrm{E} 3$ cells/well in the same plates. Cells adhered for $26-30 \mathrm{~h}$, washed once with PBS and treated for $6 \mathrm{~h}$ with vehicle, C-PAC [50-100 $\mu \mathrm{g} / \mathrm{mL}$ ], the inducer 2,3-Dimethoxy-1,4-naphthoquinone (DMNQ; $20 \mu \mathrm{M}$ final concentration; Sigma Aldrich, St. Louis, MO) and the inhibitor diethylene triamine pentaacetic acid (DTPA; $100 \mu \mathrm{M}$ final concentration; Sigma Aldrich, St. Louis, MO). After 6h, the supernatant was transferred to a new plate 
and the cells were washed. The cells, the supernatant from the cells and the reaction-no cells in medium were assayed independently for hydrogen peroxide $30 \mathrm{~min}$ after addition of the Amplex Red substrate. Fluorescence was measured using the SpectraMax ${ }^{\circledR}$ i3 with excitation/emission wavelengths of $545-590 \mathrm{~nm}$. A minimum of 4 wells were analyzed for each treatment and the data expressed as mean relative fluorescence units \pm SEM.

\subsection{Statistical analysis}

GraphPad Prism software was used to evaluate statistical significance using ANOVA with Tukey's post-hoc test. $P$-values of $<0.05$ were considered significant.

\section{Results and discussion}

\subsection{C-PAC differentially modulates ROS in EAC and BE cells}

Excess generation of ROS leads to increased oxidative stress and in turn activates intracellular signaling cascades that can lead to cellular death. Our previous results show that a number of the MAPK proteins differentially altered by C-PAC treatment in EAC cell lines belong to pathways implicated in hypoxia, ROS generation and altered bioenergetics [8]. In addition, cranberry extracts reportedly increase apoptosis of neuroblastoma and ovarian cancer cells in part through ROS generation $[6,39]$. To better understand the cell death mechanism elicited by C-PAC, we examined whether C-PAC induced or inhibited ROS following treatment of esophageal cells. We also evaluated the ability of the antioxidant NAC to mitigate these effects. JHAD1, OE33 and OE19 EAC cells were treated for 3 and $6 \mathrm{~h}$ with vehicle, C-PAC [25 and $100 \mu \mathrm{g} / \mathrm{ml}$, and the known ROS inducer TBHP $[100 \mu \mathrm{M}]$, either alone or in combination with NAC [5 mM]. ROS were detected utilizing CellROX ${ }^{\circledR}$ Green fluorescent reagent and the results are presented in Fig. 1A-B. The bar graphs show the percent change in ROS by treatment relative to ROS levels in vehicle treated cells. Numerical representation of the data is located in Table 1.

Following a $3 \mathrm{~h}$ treatment, ROS levels were significantly elevated in OE33 (8.1-fold), JHAD1 (6.0-fold) and OE19 (2.8-fold) cells with C-PAC at $100 \mu \mathrm{g} / \mathrm{mL}$ (Fig. 1A). Fluorescent images on the right side of the panel show significantly increased ROS production following treatment. The pro-oxidant TBHP strongly induced ROS in JHAD1 cells (19.8-fold) which subsequently resulted in rapid cell death by $6 \mathrm{~h}$. The antioxidant NAC mitigated TBHP induced ROS levels in JHAD1 cells at $3 \mathrm{~h}$ and $6 \mathrm{~h}$. NAC mitigated the levels of ROS produced in OE19 cells at the low dose of C-PAC [ $25 \mu \mathrm{g} / \mathrm{mL}]$ by $50 \%$, suggesting that NAC can scavenge free radicals produced from cells by C-PAC. At $6 \mathrm{~h}, \mathrm{C}$-PAC [100 $\mu \mathrm{g} / \mathrm{mL}]$ treatment significantly induced ROS in JHAD1 (10.8-fold), OE33 (6.2-fold) and OE19 (3.4-fold) cells. ROS was produced in JHAD1 cells treated with the combination of NAC and C-PAC $[100 \mu \mathrm{g} / \mathrm{mL}]$ only at the $6 \mathrm{~h}$ time point (12.1-fold). The low dose of C-PAC [25 $\mu \mathrm{g} / \mathrm{mL}]$ increased ROS levels only in OE19 when compared to vehicle. These results support that C-PAC acts as a pro-oxidant in EAC cells by increasing total ROS levels prior to cell death induction. A dose-dependent increase in the inhibition of viability was observed for C-PAC treated JHAD1 and OE19 over a 24-72 h treatment window [14]. The varying levels of ROS induction may be linked to specific cell death pathways activated by C-PAC. JHAD1 and OE33 cells have the highest levels of ROS induced by C-PAC and these cells die through low levels of apoptosis and high levels of autophagy [8, 14]. Conversely, the magnitude of ROS generation is lower in C-PAC treated OE19 cells, which mainly die through necrosis [8]. Additional research is needed to better understand activation of cell death pathways in the context of ROS induction.

We next sought to determine if C-PAC induced death of CP-C BE cells was associated with ROS induction. These premalignant dysplastic BE cells have not been characterized extensively with C-PAC but the LD50 is $100 \mu \mathrm{g} / \mathrm{mL}$ at $72 \mathrm{~h}$ post-treatment, a concentration that is behaviorally achievable in humans (Katherine M. Weh and Laura A. Kresty, unpublished data). CP-C cells were treated for 3 or $6 \mathrm{~h}$ with the same combinations used 
A

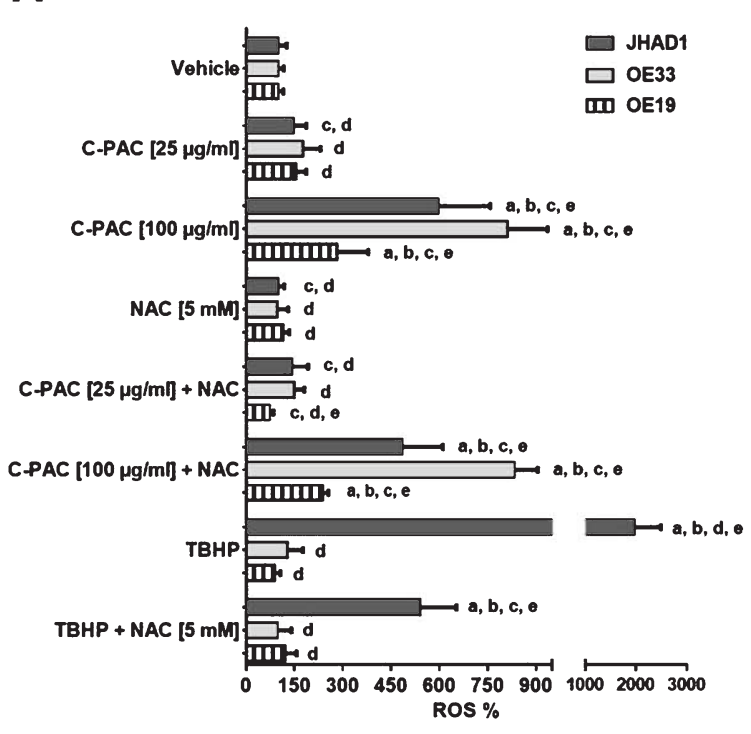

B

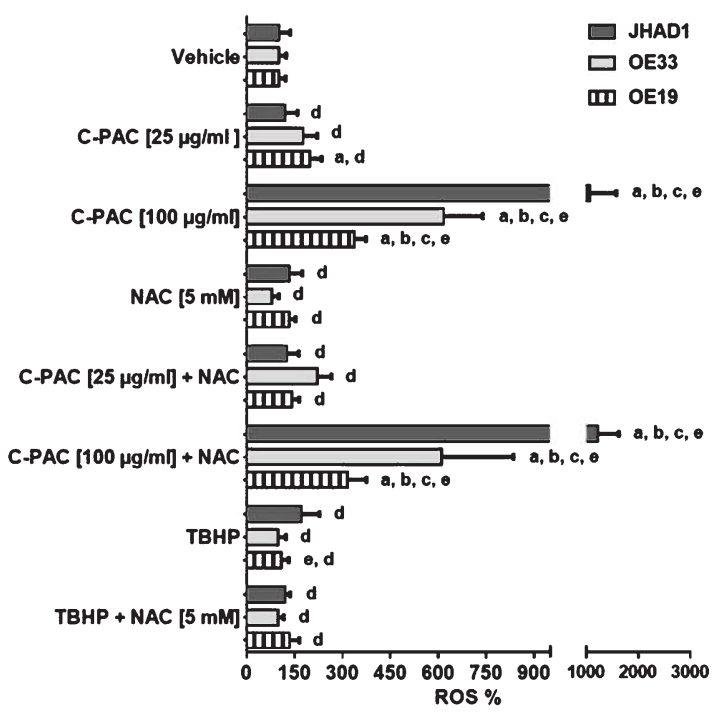

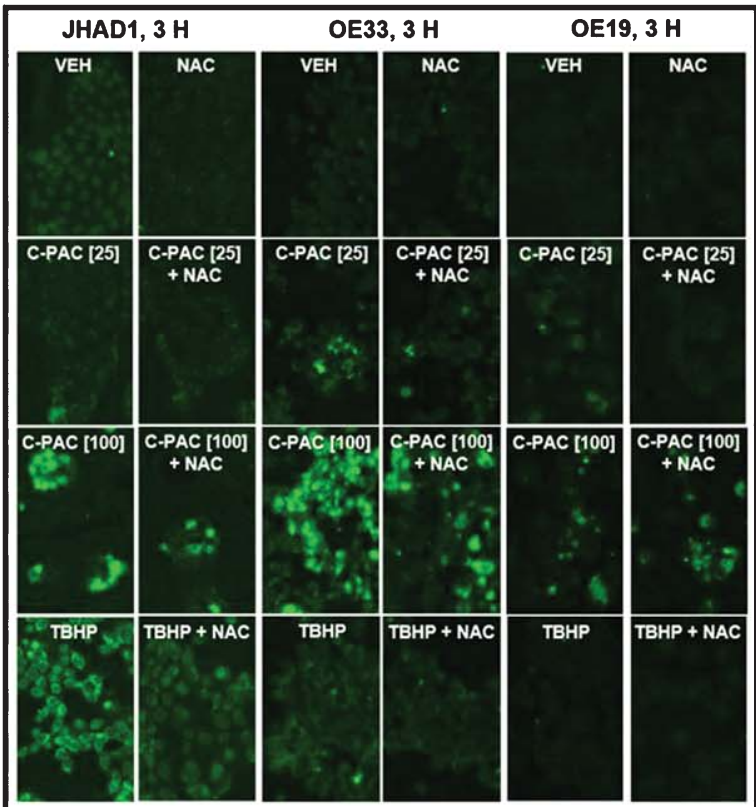

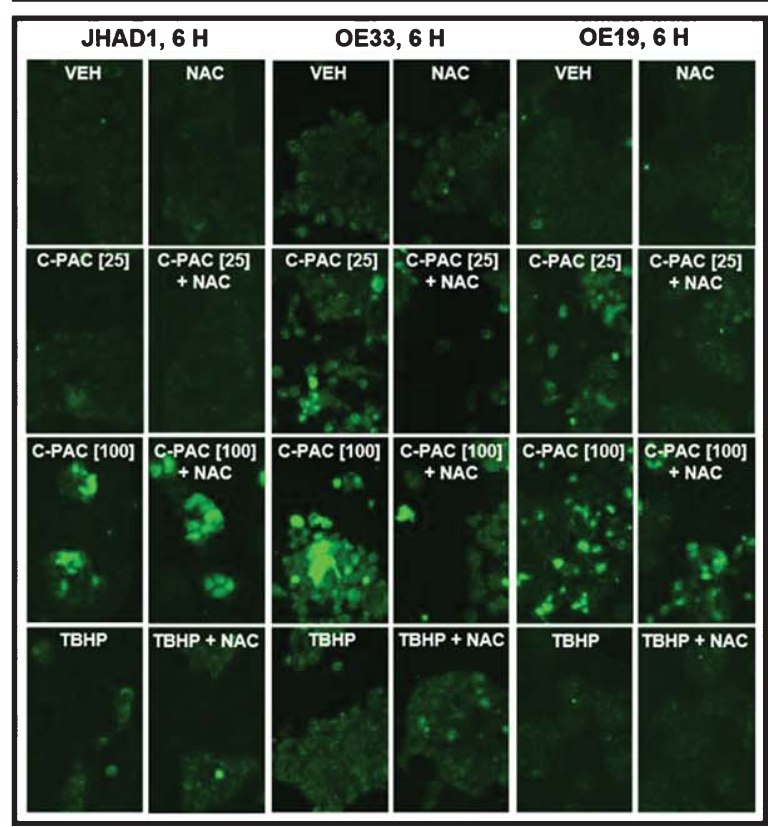

Fig. 1. C-PAC induces ROS in EAC cells. JHAD1, OE33 and OE19 cells were treated for A) $3 \mathrm{~h}$ and B) $6 \mathrm{~h}$ with vehicle, C-PAC [25 and $100 \mu \mathrm{g} / \mathrm{mL}$ ], and the known ROS inducer TBHP [100 $\mu \mathrm{M}$ ], either alone or in combination with the antioxidant NAC [5 mM]. ROS induction was detected utilizing CellROX ${ }^{\circledR}$ Green reagent coupled with the SpectraMax ${ }^{\circledR}$ MiniMax ${ }^{\mathrm{TM}}$ Imaging cytometer as described in the Materials and Methods. Representative fluorescent images are provided where green fluorescent or light grey if viewing image in greyscale signal denotes ROS detection by the CellROX ${ }^{\circledR}$ Green reagent. ROS modulation data are expressed as mean percentage of vehicle treated cells \pm SEM. Statistical significance was assessed by ANOVA with Tukey's post-hoc test $(P<0.05)$. Treatments were significantly different from $\mathrm{a}=$ vehicle, $\mathrm{b}=\mathrm{NAC}[5 \mathrm{mM}], \mathrm{c}=\mathrm{TBHP}[100 \mu \mathrm{M}], \mathrm{d}=\mathrm{C}-\mathrm{PAC}[100 \mu \mathrm{g} / \mathrm{mL}]$ and e $=\mathrm{C}-\mathrm{PAC}[25 \mu \mathrm{g} / \mathrm{mL}]$. 
Table 1

ROS induction levels as measured by the CellROX ${ }^{\circledR}$ green oxidative stress assay

\begin{tabular}{|c|c|c|c|c|}
\hline & JHAD1 & OE33 & OE19 & $\mathrm{CP}-\mathrm{C}$ \\
\hline \multicolumn{5}{|l|}{$3 h$ Treatment } \\
\hline VEH & $100.0 \pm 6.8$ & $100.0 \pm 5.5$ & $100.0 \pm 6.8$ & $100.0 \pm 2.8$ \\
\hline C-PAC [25] & $147.6 \pm 18.6$ & $176.8 \pm 22.2$ & $164.8 \pm 9.6$ & $86.9 \pm 4.0^{\mathrm{a}}$ \\
\hline C-PAC [100] & $579.9 \pm 80.3^{\mathrm{a}}$ & $813.6 \pm 29.1^{\mathrm{a}}$ & $295.3 \pm 42.0^{\mathrm{a}}$ & $100.8 \pm 2.0$ \\
\hline NAC & $98.4 \pm 10.2$ & $95.4 \pm 10.1$ & $113.4 \pm 8.8$ & $103.1 \pm 2.6$ \\
\hline C-PAC [25] + NAC & $154.9 \pm 21.2$ & $148.9 \pm 18.3$ & $74.1 \pm 5.5$ & $64.5 \pm 1.8^{\mathrm{a}}$ \\
\hline C-PAC $[100]+\mathrm{NAC}$ & $473.4 \pm 55.4^{\mathrm{a}}$ & $834.4 \pm 25.0^{\mathrm{a}}$ & $234.6 \pm 7.1^{\mathrm{a}}$ & $79.8 \pm 2.7^{\mathrm{a}}$ \\
\hline ТВHP & $2115.1 \pm 174.1^{\mathrm{a}}$ & $128.2 \pm 12.5$ & $85.6 \pm 8.4$ & $113.5 \pm 1.2^{\mathrm{a}}$ \\
\hline $\mathrm{TBHP}+\mathrm{NAC}$ & $540.7 \pm 69.6^{\mathrm{a}}$ & $97.2 \pm 17.2$ & $114.3 \pm 14.8$ & $95.5 \pm 2.7$ \\
\hline \multicolumn{5}{|l|}{$6 h$ Treatment } \\
\hline VEH & $100.0 \pm 11.7$ & $100.0 \pm 5.8$ & $100.0 \pm 6.9$ & $100.0 \pm 6.3$ \\
\hline C-PAC [25] & $119.4 \pm 17.9$ & $177.5 \pm 18.0$ & $198.0 \pm 14.7^{\mathrm{a}}$ & $56.3 \pm 4.2^{\mathrm{a}}$ \\
\hline C-PAC [100] & $1079.5 \pm 204.7^{\mathrm{a}}$ & $617.1 \pm 35.2^{\mathrm{a}}$ & $337.5 \pm 14.7^{\mathrm{a}}$ & $21.0 \pm 2.4^{\mathrm{a}}$ \\
\hline NAC & $133.3 \pm 18.4$ & $79.7 \pm 8.6$ & $132.5 \pm 9.1$ & $107.1 \pm 9.7$ \\
\hline C-PAC [25] + NAC & $126.3 \pm 16.5$ & $220.7 \pm 20.7$ & $141.9 \pm 10.1$ & $34.2 \pm 1.4^{\mathrm{a}}$ \\
\hline C-PAC $[100]+\mathrm{NAC}$ & $1214.4 \pm 185.0^{\mathrm{a}}$ & $610.9 \pm 67.8^{\mathrm{a}}$ & $323.7 \pm 24.9^{\mathrm{a}}$ & $31.2 \pm 0.9^{\mathrm{a}}$ \\
\hline TBHP & $169.9 \pm 23.8$ & $97.2 \pm 7.7$ & $108.8 \pm 10.3$ & $110.3 \pm 13.3$ \\
\hline $\mathrm{TBHP}+\mathrm{NAC}$ & $119.0 \pm 7.0$ & $98.3 \pm 8.9$ & $134.3 \pm 13.8$ & $113.9 \pm 8.6$ \\
\hline
\end{tabular}

ROS induction levels were calculated for each treatment and are expressed as a mean percentage of vehicle treated cells \pm SEM. Statistical significance from VEH was assessed by ANOVA with Tukey's post-hoc test $(P<0.05)$ and denoted by ${ }^{\text {a }}$. Comprehensive tests of statistical significance are reported in Figs. 1 and 2.

for the EAC cells (Fig. 2A-B). C-PAC has little effect on ROS levels at $3 \mathrm{~h}$, regardless of concentration (Fig. 2A). However, when C-PAC is combined with NAC, there is a significant reduction in ROS levels at both doses of C-PAC at $3 \mathrm{~h}$. Following $6 \mathrm{~h}$ of treatment, $25 \mu \mathrm{g} / \mathrm{mL}$ and $100 \mu \mathrm{g} / \mathrm{mL}$ C-PAC significantly reduced ROS levels by $44 \%$ and $79 \%$, respectively. While NAC alone had no effect on ROS modulation at $6 \mathrm{~h}$, the combination of NAC + C-PAC $[25 \mu \mathrm{g} / \mathrm{mL}]$ and NAC + C-PAC $[100 \mu \mathrm{g} / \mathrm{mL}]$ resulted in significant reductions in ROS by $66 \%$ and $36 \%$, respectively. Thus, NAC added to the ROS reducing effects of C-PAC [ $25 \mu \mathrm{g} / \mathrm{mL}$ ] but not at the higher concentration. Of note, baseline levels of ROS in vehicle treated CP-C cells at $3 \mathrm{~h}$ and $6 \mathrm{~h}$ appear higher in the BE cells compared to all the EAC lines tested (Fig. 2B). Collectively, these data support that C-PAC acts as an antioxidant in CP-C BE cells by decreasing the total ROS levels; yet, as a pro-oxidant in EAC cells, both leading to cell death downstream.

The literature is divided on the reporting of cranberry juice and extracts as having either antioxidant or prooxidant characteristics. Most in vivo and clinical trial studies show that cranberries are powerful antioxidants decreasing lipid oxidation, cholesterol and mean arterial blood pressure [45-50]. In vitro studies using cancer cell lines show that cranberry juices and extracts can act as both antioxidants [51,52] and pro-oxidants [6, 39]. The studies that show the antioxidant capacity of cranberry juices and extracts are mostly conducted in the absence of cells, potentially measuring the chemical reaction but with uncertain biological relevance [53-56]. The ability for C-PAC to induce ROS as a potential cell death mechanism in EAC cells is consistent with EAC chemotherapy using cisplatin to further increase ROS levels as a mode of cell death induction. The reduction of ROS in CP-C BE cells by C-PAC suggests that the cell death mechanism may be different in these premalignant cells compared to the EAC cells. 
A

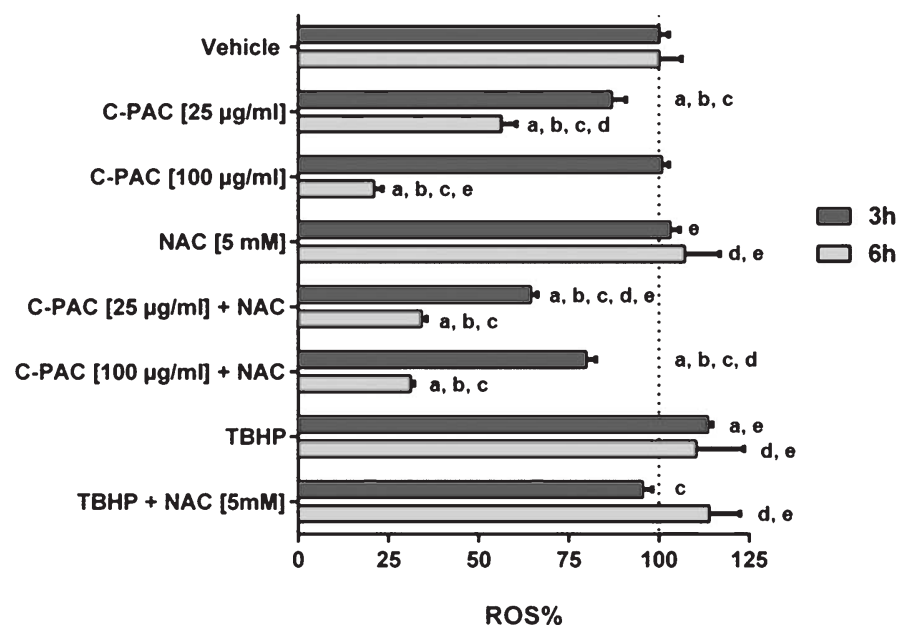

B

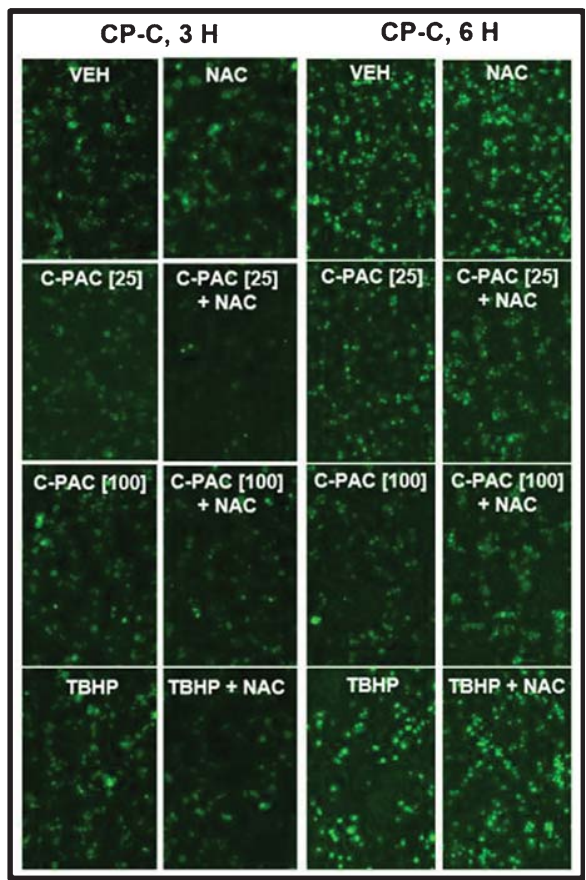

Fig. 2. C-PAC reduces ROS in CP-C BE cells. CP-C BE cells were treated for A) $3 \mathrm{~h}$ and $6 \mathrm{~h}$ with vehicle, $\mathrm{C}-\mathrm{PAC}[25$ and $100 \mu \mathrm{g} / \mathrm{mL}]$, and the known ROS inducer TBHP [100 $\mu \mathrm{M}$ ], either alone or in combination with the antioxidant NAC [5 mM]. ROS induction was detected utilizing CellROX ${ }^{\circledR}$ Green reagent coupled with the SpectraMax ${ }^{\circledR}$ MiniMax ${ }^{\text {TM }}$ Imaging cytometer as described in the Materials and Methods. B) Representative fluorescent images are provided where green fluorescent or light grey if viewing image in greyscale signal denotes ROS detection by the CellROX ${ }^{\circledR}$ Green reagent. ROS modulation data are expressed as mean percentage of vehicle treated cells \pm SEM. Statistical significance was assessed by ANOVA with Tukey's post -hoc test $(P<0.05)$. Treatments were significantly different from a $=$ vehicle, $\mathrm{b}=\mathrm{NAC}$ $[5 \mathrm{mM}], \mathrm{c}=\mathrm{TBHP}[100 \mu \mathrm{M}], \mathrm{d}=\mathrm{C}-\mathrm{PAC}[100 \mu \mathrm{g} / \mathrm{mL}]$ and $\mathrm{e}=\mathrm{C}-\mathrm{PAC}[25 \mu \mathrm{g} / \mathrm{mL}]$.

\subsection{Hydrogen peroxide levels increase in EAC cells treated with C-PAC}

In general, the CellROX ${ }^{\circledR}$ green reagent is used to monitor total ROS levels with preference for superoxide, singlet oxygen and hydroxyl radical. To begin identifying the specific ROS induced by C-PAC in EAC cells, we utilized the fluorescence based Amplex Red hydrogen peroxide assay. JHAD1, OE19 and CP-C cells were treated with C-PAC [50-100 $\mu \mathrm{g} / \mathrm{mL}$ ], $20 \mu \mathrm{M}$ DMNQ and $100 \mu \mathrm{M}$ DTPA for $6 \mathrm{~h}$. DMNQ was used as a positive control for the production of hydrogen peroxide and DTPA was used to account for any trace metal interactions with the substrate [57-59]. The treated cells, the supernatant from the treated cells and the reaction-no cells in the medium were analyzed independently for hydrogen peroxide levels. The reaction-no cells is the C-PAC treatment added to the Amplex Red reagents in the absence of any cells.

A significant dose-dependent increase in hydrogen peroxide was observed in JHAD1 cells treated with $50-100 \mu \mathrm{g} / \mathrm{mL}$ C-PAC (Fig. 3A). Only the high dose of C-PAC [100 $\mu \mathrm{g} / \mathrm{mL}]$ significantly induced hydrogen peroxide in OE19 cells (Fig. 3B). DMNQ produced a significant increase in hydrogen peroxide from JHAD1 (11.5-fold) and OE19 (3.4-fold) cells as expected. DTPA increased hydrogen peroxide levels in JHAD1 cells incubated with Amplex red but not in the supernatant collected from treated JHAD1 cells. Hydrogen peroxide levels measured from the supernatant of JHAD1 and OE19 cells treated with C-PAC was significantly increased at both concentrations but the magnitude of increase in the supernatant closely mimicked the levels of hydrogen 

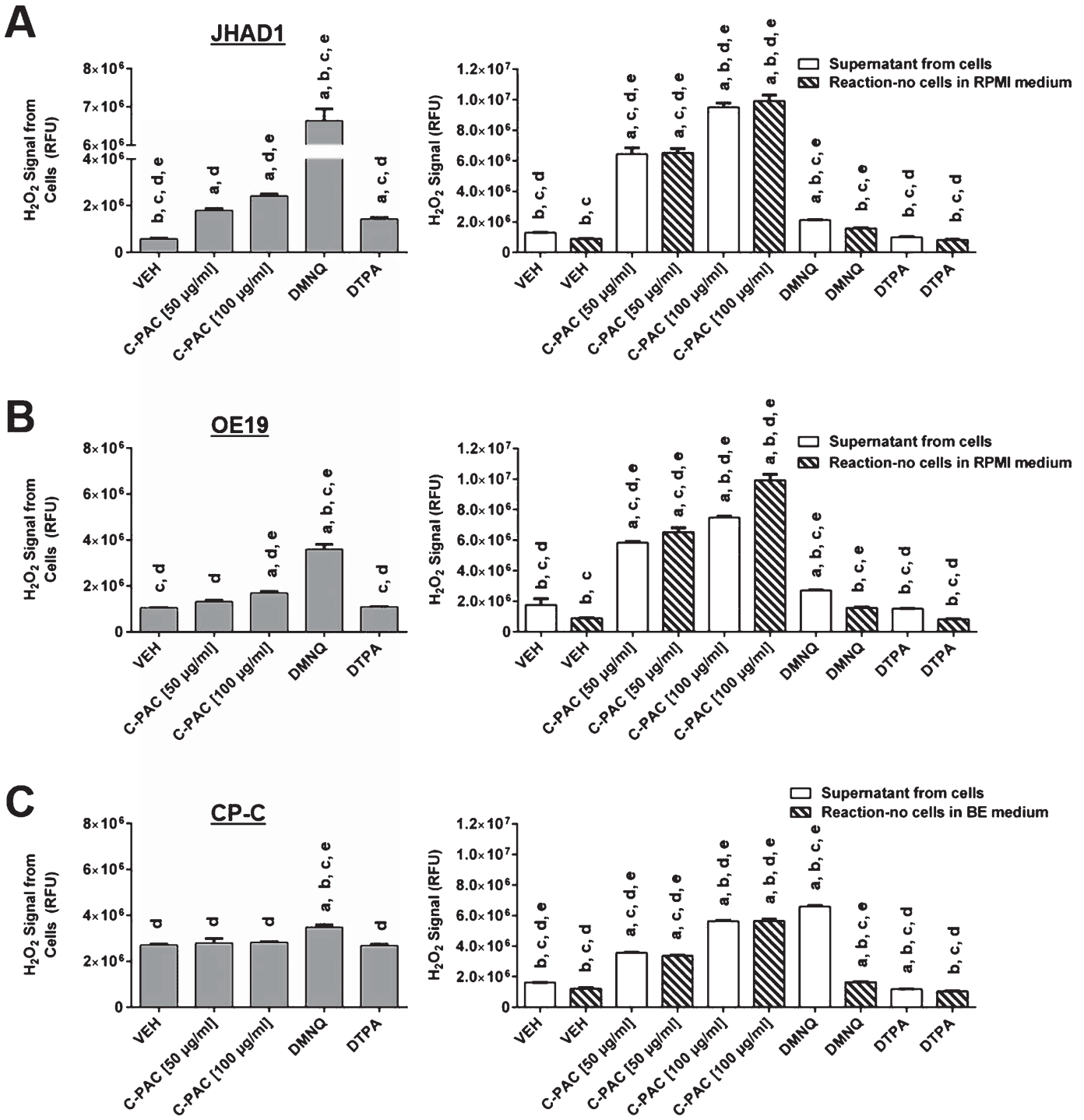

Fig. 3. Hydrogen peroxide levels increase or are unchanged in C-PAC treated EAC and BE cells, respectively. The Amplex Red assay was used to measure hydrogen peroxide levels from A) JHAD1, B) OE19 and C) CP-C cells following treatment for $6 \mathrm{~h}$ with C-PAC [50 and $100 \mu \mathrm{g} / \mathrm{mL}$ ], $20 \mu \mathrm{M}$ DMNQ and $100 \mu \mathrm{M}$ DTPA. The supernatant from the cells was transferred to a new plate, the cells were washed once with medium (no FBS) and the reaction-no cells in media were assessed independently for hydrogen peroxide. The reaction-no cells is the C-PAC treatment added to the Amplex Red reagents in the absence of any cells. It was incubated for $6 \mathrm{~h}$ at $37^{\circ} \mathrm{C}$ and $5 \% \mathrm{CO}_{2}$ alongside the plate that contained cells and treatment. Fluorescence was measured as described in the Materials and Methods and data are presented as mean relative fluorescence units \pm SEM. Statistical significance was assessed by ANOVA with Tukey's post-hoc test $(P<0.05)$. Treatments were significantly different from $\mathrm{a}=$ vehicle, $\mathrm{b}=\mathrm{C}-\mathrm{PAC}[50 \mu \mathrm{g} / \mathrm{mL}], \mathrm{c}=\mathrm{C}-\mathrm{PAC}[100 \mu \mathrm{g} / \mathrm{mL}], \mathrm{d}=$ DMNQ $[20 \mu \mathrm{M}]$ and e $=$ DTPA $[100 \mu \mathrm{M}]$.

peroxide detected in the reaction-no cells in RPMI medium alone. The high background of the reaction in RPMI media without cells was alarming and supports that C-PAC may be directly interacting with the Amplex Red substrate, resulting in spuriously elevated hydrogen peroxide levels. It is possible that the inherent structure of 
C-PAC, with multiple vicinal hydroxyl groups, may be generating ROS within the reaction solution or promoting the oxidation of Amplex red to resorufin [1,60]. Thus, our data supports that C-PAC significantly induces intracellular hydrogen peroxide in EAC cells, but measurements solely focused on the supernatant may be confounded and not reliable.

Hydrogen peroxide levels in CP-C BE cells were unchanged following a $6 \mathrm{~h}$ treatment with C-PAC [50 and $100 \mu \mathrm{g} / \mathrm{mL}$ ] or DTPA (Fig. 3C). A significant increase in hydrogen peroxide was observed from CP-C cells treated with the positive control DMNQ, although at a lower magnitude than the EAC cells (1.3-fold compared to 3.4- and 11.5-fold in OE19 and JHAD1 cells, respectively). Background levels of hydrogen peroxide were higher in CP-C cells compared to both EAC cell lines, which is in agreement with the increased ROS levels observed in the CellROX ${ }^{\circledR}$ green assay (Fig. 2B). Also consistent with the high background observed in the reaction-no cells in RPMI, the reaction-no cells in BE medium accounted for nearly the entire signal measured in the supernatant from the cells, with the exception of DMNQ. These results suggest that hydrogen peroxide is not the specific ROS decreased in CP-C BE cells treated with C-PAC. Hydrogen peroxide is readily broken down to water and oxygen by catalase, an enzyme with significantly higher activity in healthy patients compared to those with esophageal cancer [61]. This may explain why hydrogen peroxide levels increase in EAC lines following C-PAC treatment; yet, do not change in premalignant CP-C BE cells. The antioxidant and pro-oxidant activities of C-PAC in premalignant BE and EAC cancer lines argues that for use in clinical trials, the oxidative environment may dictate the activity of this natural product. The utilization of antioxidants, particularly in the form of supplements at super physiological levels, have not been efficacious and in the case of beta carotene, actually deleterious $[62,63]$. Clinical trials utilizing cranberries or cranberry derived products to target cancer are currently lacking; however, other food derived agents rich in polyphenols, such as black raspberries, have reported positive effects in cancer or premalignancy targeting the aerodigestive tract [64-68]. The current study was limited by its in vitro nature and the ability of C-PAC to mitigate ROS in vivo remains unknown. We are currently investigating the inhibitory mechanisms of C-PAC in a rodent surgical model for EAC. Future studies will be necessary to interrogate additional oxygen radicals for their contribution to C-PAC induced ROS. Finally, examination of reactive nitrogen species including free radical nitric oxide (NO) following C-PAC treatment will be relevant as NO levels are elevated in patients with BE [69].

\section{Acknowledgments}

We thank Dr. James R. Eshleman (Johns Hopkins University, Baltimore, MD) for sharing the JH-ESOAd1 cell line utilized in these studies. We thank the National Institutes of Health and National Cancer Institute for funding support via grant (RO1-CA158319) and Advancing a Healthier Wisconsin (5220296) for equipment funds, both awarded to Laura A. Kresty.

\section{References}

[1] Pappas E, Schaich KM. Phytochemicals of cranberries and cranberry products: Characterization, potential health effects, and processing stability. Crit Rev Food Sci Nutr. 2009;49(9):741-81.

[2] Blumberg JB, Camesano TA, Cassidy A, Kris-Etherton P, Howell A, Manach C, et al. Cranberries and their bioactive constituents in human health. Adv Nutr. 2013;4(6):618-32.

[3] Neto CC. Cranberry and blueberry: Evidence for protective effects against cancer and vascular diseases. Mol Nutr Food Res. 2007;51(6):652-64.

[4] Deziel B, MacPhee J, Patel K, Catalli A, Kulka M, Neto C, et al. American cranberry (Vaccinium macrocarpon) extract affects human prostate cancer cell growth via cell cycle arrest by modulating expression of cell cycle regulators. Food Funct. 2012;3(5):556-64.

[5] Deziel BA, Patel K, Neto C, Gottschall-Pass K, Hurta RA. Proanthocyanidins from the American Cranberry (Vaccinium macrocarpon) inhibit matrix metalloproteinase- 2 and matrix metalloproteinase- 9 activity in human prostate cancer cells via alterations in multiple cellular signalling pathways. J Cell Biochem. 2010;111(3):742-54. 
[6] Kim KK, Singh AP, Singh RK, Demartino A, Brard L, Vorsa N, et al. Anti-angiogenic activity of cranberry proanthocyanidins and cytotoxic properties in ovarian cancer cells. Int J Oncol. 2012;40(1):227-35.

[7] Kresty LA, Howell AB, Baird M. Cranberry proanthocyanidins mediate growth arrest of lung cancer cells through modulation of gene expression and rapid induction of apoptosis. Molecules. 2011;16(3):2375-90.

[8] Kresty LA, Weh KM, Zeyzus-Johns B, Perez LN, Howell AB. Cranberry proanthocyanidins inhibit esophageal adenocarcinoma in vitro and in vivo through pleiotropic cell death induction and PI3K/AKT/mTOR inactivation. Oncotarget. 2015;6(32):33438-55.

[9] MacLean MA, Scott BE, Deziel BA, Nunnelley MC, Liberty AM, Gottschall-Pass KT, et al. North American cranberry (Vaccinium macrocarpon) stimulates apoptotic pathways in DU145 human prostate cancer cells in vitro. Nutr Cancer. 2011;63(1):109-20.

[10] Onitilo AA, Berg RL, Engel JM, Stankowski RV, Glurich I, Williams GM, et al. Prostate cancer risk in pre-diabetic men: A matched cohort study. Clin Med Res. 2013;11(4):201-9.

[11] Onitilo AA, Donald M, Stankowski RV, Engel JM, Williams G, Doi SA. Breast and prostate cancer survivors in a diabetic cohort: Results from the Living with Diabetes Study. Clin Med Res. 2013;11(4):210-8.

[12] Sun J, Hai Liu R. Cranberry phytochemical extracts induce cell cycle arrest and apoptosis in human MCF-7 breast cancer cells. Cancer Lett. 2006;241(1):124-34.

[13] Wang Y, Han A, Chen E, Singh RK, Chichester CO, Moore RG, et al. The cranberry flavonoids PAC DP-9 and quercetin aglycone induce cytotoxicity and cell cycle arrest and increase cisplatin sensitivity in ovarian cancer cells. Int J Oncol. 2015;46(5):1924-34.

[14] Weh KM, Howell A, Kresty LA. Expression, modulation, and clinical correlates of the autophagy protein Beclin-1 in esophageal adenocarcinoma. Mol Carcinog. In press 2015.

[15] Boateng J, Verghese M, Shackelford L, Walker LT, Khatiwada J, Ogutu S, et al. Selected fruits reduce azoxymethane (AOM)-induced aberrant crypt foci (ACF) in Fisher 344 male rats. Food Chem Toxicol. 2007;45(5):725-32.

[16] Prasain JK, Jones K, Moore R, Barnes S, Leahy M, Roderick R, et al. Effect of cranberry juice concentrate on chemically-induced urinary bladder cancers. Oncol Rep. 2008;19(6):1565-70.

[17] Howell AB, Foxman B. Cranberry juice and adhesion of antibiotic-resistant uropathogens. JAMA. 2002;287(23):3082-3.

[18] Howell AB, Vorsa N, Der Marderosian A, Foo LY. Inhibition of the adherence of P-fimbriated Escherichia coli to uroepithelial-cell surfaces by proanthocyanidin extracts from cranberries. The New Eng J Med. 1998;339(15):1085-6.

[19] Foo LY, Lu Y, Howell AB, Vorsa N. The structure of cranberry proanthocyanidins which inhibit adherence of uropathogenic P-fimbriated Escherichia coli in vitro. Phytochemistry. 2000;54(2):173-81.

[20] Foo LY, Lu Y, Howell AB, Vorsa N. A-Type proanthocyanidin trimers from cranberry that inhibit adherence of uropathogenic P-fimbriated Escherichia coli. J Nat Prod. 2000;63(9):1225-8.

[21] Neto CC, Amoroso JW, Liberty AM. Anticancer activities of cranberry phytochemicals: An update. Mol Nutri Food Res. 2008;52(Suppl 1):S18-27.

[22] American Cancer Society. Cancer Facts \& Figures 2015. Atlanta: American Cancer Society; 2015.

[23] Howlader N, Noone AM, Krapcho M, et al. SEER Cancer Statistics Review, 1975-2011, National Cancer Institute. Bethesda, MD, http://seer.cancer.gov/csr/1975_2011/, based on November 2013 SEER data submission, posted to the SEER web site, April 2014.

[24] Dawsey SM, Fagundes RB, Jacobson BC, Kresty LA, Mallery SR, Paski S, et al. Diet and esophageal disease. Ann N Y Acad Sci. 2014;1325:127-37.

[25] Napier KJ, Scheerer M, Misra S. Esophageal cancer: A Review of epidemiology, pathogenesis, staging workup and treatment modalities. World J Gastrointest Oncol. 2014;6(5):112-20.

[26] Spechler SJ, Souza RF. Barrett's esophagus. New Engl J Med. 2014;371(9):836-45.

[27] Li X, Galipeau PC, Paulson TG, Sanchez CA, Arnaudo J, Liu K, et al. Temporal and spatial evolution of somatic chromosomal alterations: A case-cohort study of Barrett's esophagus. Cancer Prev Res (Phila). 2014;7(1):114-27.

[28] Li X, Paulson TG, Galipeau PC, Sanchez CA, Liu K, Kuhner MK, et al. Assessment of Esophageal Adenocarcinoma Risk Using Somatic Chromosome Alterations in Longitudinal Samples in Barrett's Esophagus. Cancer Prev Res (Phila). 2015;8(9):845-56.

[29] Ling LU, Tan KB, Lin H, Chiu GN. The role of reactive oxygen species and autophagy in safingol-induced cell death. Cell Death Dis. 2011;2:e129.

[30] Kroemer G. Autophagy: A druggable process that is deregulated in aging and human disease. J Clin Invest. 2015;125(1):1-4.

[31] Scherz-Shouval R, Elazar Z. ROS, mitochondria and the regulation of autophagy. Trends Cell Biol. 2007;17(9):422-7.

[32] Liou GY, Storz P. Reactive oxygen species in cancer. Free Radic Res. 2010;44(5):479-96.

[33] Hileman EO, Liu J, Albitar M, Keating MJ, Huang P. Intrinsic oxidative stress in cancer cells: A biochemical basis for therapeutic selectivity. Cancer Chemother Pharmacol. 2004;53(3):209-19.

[34] Marengo B, Raffaghello L, Pistoia V, Cottalasso D, Pronzato MA, Marinari UM, et al. Reactive oxygen species: Biological stimuli of neuroblastoma cell response. Cancer Lett. 2005;228(1-2):111-6. 
[35] O'Donovan TR, O'Sullivan GC, McKenna SL. Induction of autophagy by drug-resistant esophageal cancer cells promotes their survival and recovery following treatment with chemotherapeutics. Autophagy. 2011;7(5):509-24.

[36] Osone S, Hosoi H, Kuwahara Y, Matsumoto Y, Iehara T, Sugimoto T. Fenretinide induces sustained-activation of JNK/p38 MAPK and apoptosis in a reactive oxygen species-dependent manner in neuroblastoma cells. Int J Cancer. 2004;112(2):219-24.

[37] Kavanagh ME, O'Sullivan KE, O'Hanlon C, O'Sullivan JN, Lysaght J, Reynolds JV. The esophagitis to adenocarcinoma sequence; the role of inflammation. Cancer Lett. 2014;345(2):182-9.

[38] Farhadi A, Fields J, Banan A, Keshavarzian A. Reactive oxygen species: Are they involved in the pathogenesis of GERD, Barrett's esophagus, and the latter's progression toward esophageal cancer? Am J Gastroenterol. 2002;97(1):22-6.

[39] Singh AP, Lange TS, Kim KK, Brard L, Horan T, Moore RG, et al. Purified cranberry proanthocyanidines (PAC-1A) cause proapoptotic signaling, ROS generation, cyclophosphamide retention and cytotoxicity in high-risk neuroblastoma cells. Int J Oncol. 2012;40(1):99-108.

[40] Howell AB, Botto H, Combescure C, Blanc-Potard AB, Gausa L, Matsumoto T, et al. Dosage effect on uropathogenic Escherichia coli anti-adhesion activity in urine following consumption of cranberry powder standardized for proanthocyanidin content: A multicentric randomized double blind study. BMC Infect Dis. 2010;10:94.

[41] Howell AB, Reed JD, Krueger CG, Winterbottom R, Cunningham DG, Leahy M. A-type cranberry proanthocyanidins and uropathogenic bacterial anti-adhesion activity. Phytochemistry. 2005;66(18):2281-91.

[42] Krueger CG, Reed JD, Feliciano RP, Howell AB. Quantifying and characterizing proanthocyanidins in cranberries in relation to urinary tract health. Anal Bioanal Chem. 2013;405(13):4385-95.

[43] Kresty LA, Clarke J, Ezell K, Exum A, Howell AB, Guettouche T. MicroRNA alterations in Barrett's esophagus, esophageal adenocarcinoma, and esophageal adenocarcinoma cell lines following cranberry extract treatment: Insights for chemoprevention. J Carcinog. 2011;10:34.

[44] Kresty LA, Howell AB, Baird M. Cranberry proanthocyanidins induce apoptosis and inhibit acid-induced proliferation of human esophageal adenocarcinoma cells. J Agric Food Chem. 2008;56(3):676-80.

[45] Anhe FF, Roy D, Pilon G, Dudonne S, Matamoros S, Varin TV, et al. A polyphenol-rich cranberry extract protects from diet-induced obesity, insulin resistance and intestinal inflammation in association with increased Akkermansia spp. population in the gut microbiota of mice. Gut. 2015;64(6):872-83.

[46] Kim MJ, Jung HN, Kim KN, Kwak HK. Effects of cranberry powder on serum lipid profiles and biomarkers of oxidative stress in rats fed an atherogenic diet. Nutr Res Pract. 2008;2(3):158-64.

[47] Mathison BD, Kimble LL, Kaspar KL, Khoo C, Chew BP. Consumption of cranberry beverage improved endogenous antioxidant status and protected against bacteria adhesion in healthy humans: A randomized controlled trial. Nutr Res. 2014;34(5):420-7.

[48] Novotny JA, Baer DJ, Khoo C, Gebauer SK, Charron CS. Cranberry juice consumption lowers markers of cardiometabolic risk, including blood pressure and circulating C-reactive protein, triglyceride, and glucose concentrations in adults. J Nutr. 2015;145(6):1185-93.

[49] Valentova K, Stejskal D, Bednar P, Vostalova J, Cihalik C, Vecerova R, et al. Biosafety, antioxidant status, and metabolites in urine after consumption of dried cranberry juice in healthy women: A pilot double-blind placebo-controlled trial. J Agric Food Chem. 2007;55(8):3217-24.

[50] Vinson JA, Bose P, Proch J, Al Kharrat H, Samman N. Cranberries and cranberry products: Powerful in vitro, ex vivo, and in vivo sources of antioxidants. J Agric Food Chem. 2008;56(14):5884-91.

[51] Denis MC, Desjardins Y, Furtos A, Marcil V, Dudonne S, Montoudis A, et al. Prevention of oxidative stress, inflammation and mitochondrial dysfunction in the intestine by different cranberry phenolic fractions. Clin Sci (Lond). 2015;128(3):197-212.

[52] Martin MA, Ramos S, Mateos R, Marais JPJ, Bravo-Clemente L, Khoo C, et al. Chemical characterization and chemo-protective activity of cranberry phenolic powders in a model cell culture. Response of the antioxidant defenses and regulation of signaling pathways. Food Res Int. 2015;71:68-82.

[53] Chu YF, Liu RH. Cranberries inhibit LDL oxidation and induce LDL receptor expression in hepatocytes. Life Sci. 2005;77(15):1892901.

[54] Wang SY, Jiao H. Scavenging capacity of berry crops on superoxide radicals, hydrogen peroxide, hydroxyl radicals, and singlet oxygen. J Agric Food Chem. 2000;48(11):5677-84.

[55] Wilson T, Porcari JP, Harbin D. Cranberry extract inhibits low density lipoprotein oxidation. Life Sci. 1998;62(24):PL381-6.

[56] Wojnicz D, Sycz Z, Walkowski S, Gabrielska J, Aleksandra W, Alicja K, et al. Study on the influence of cranberry extract Zuravit S.O.S((R)) on the properties of uropathogenic Escherichia coli strains, their ability to form biofilm and its antioxidant properties. Phytomedicine. 2012;19(6):506-14.

[57] Shen L, Zhao HY, Du J, Wang F. Anti-tumor activities of four chelating agents against human neuroblastoma cells. In Vivo. 2005;19(1):233-6.

[58] Shi M, Gozal E, Choy HA, Forman HJ. Extracellular glutathione and gamma-glutamyl transpeptidase prevent $\mathrm{H} 2 \mathrm{O} 2$-induced injury by 2,3-dimethoxy-1,4-naphthoquinone. Free Radic Biol Med. 1993;15(1):57-67. 
[59] Watanabe N, Forman HJ. Autoxidation of extracellular hydroquinones is a causative event for the cytotoxicity of menadione and DMNQ in A549-S cells. Arch Biochem Biophys. 2003;411(1):145-57.

[60] Zielonka J, Zielonka M, Sikora A, Adamus J, Joseph J, Hardy M, et al. Global profiling of reactive oxygen and nitrogen species in biological systems: High-throughput real-time analyses. J Biol Chem. 2012;287(5):2984-95.

[61] Demir H, Akkus ZA, Cebi A, Cakir T, Izmirli M. Catalase, carbonic anhydrase and other biochemical parameters in esophageal cancers in Turkey. Asian Pac J Cancer Prev. 2010;11(4):1029-32.

[62] The effect of vitamin E and beta carotene on the incidence of lung cancer and other cancers in male smokers. The Alpha-Tocopherol, Beta Carotene Cancer Prevention Study Group. New Engl J Med. 1994;330(15):1029-35.

[63] Omenn GS, Goodman G, Thornquist M, Grizzle J, Rosenstock L, Barnhart S, et al. The beta-carotene and retinol efficacy trial (CARET) for chemoprevention of lung cancer in high risk populations: Smokers and asbestos-exposed workers. Cancer Res. 1994;54(7 Suppl):2038s-43s.

[64] Kresty LA, Frankel WL, Hammond CD, Baird ME, Mele JM, Stoner GD, et al. Transitioning from preclinical to clinical chemopreventive assessments of lyophilized black raspberries: Interim results show berries modulate markers of oxidative stress in Barrett's esophagus patients. Nutr Cancer. 2006;54(1):148-56.

[65] Mallery SR, Tong M, Shumway BS, Curran AE, Larsen PE, Ness GM, et al. Topical application of a mucoadhesive freeze-dried black raspberry gel induces clinical and histologic regression and reduces loss of heterozygosity events in premalignant oral intraepithelial lesions: Results from a multicentered, placebo-controlled clinical trial. Clin Cancer Res. 2014;20(7):1910-24.

[66] Mentor-Marcel RA, Bobe G, Sardo C, Wang LS, Kuo CT, Stoner G, et al. Plasma cytokines as potential response indicators to dietary freeze-dried black raspberries in colorectal cancer patients. Nutr Cancer. 2012;64(6):820-5.

[67] Shumway BS, Kresty LA, Larsen PE, Zwick JC, Lu B, Fields HW, et al. Effects of a topically applied bioadhesive berry gel on loss of heterozygosity indices in premalignant oral lesions. Clin Cancer Res. 2008;14(8):2421-30.

[68] Wang LS, Arnold M, Huang YW, Sardo C, Seguin C, Martin E, et al. Modulation of genetic and epigenetic biomarkers of colorectal cancer in humans by black raspberries: A phase I pilot study. Clin Cancer Res. 2011;17(3):598-610.

[69] Grisham MB, Jourd'heuil D, Wink DA. Review article: Chronic inflammation and reactive oxygen and nitrogen metabolismimplications in DNA damage and mutagenesis. Aliment Pharmacol Ther. 2000;14(Suppl 1):3-9. 